\title{
Application of laparoscopic artificial insemination in conventional Lacaune sheep farm using frozen-thawed semen
}

\author{
Zemenu Birhan Zegeye - Nóra Vass - Andualem Tonamo \\ University of Debrecen, Faculty of Agricultural and Food Sciences and Environmental Management, Department of Animal Husbandry \\ Engineering, Debrecen, Hungary \\ zemy.biot@gmail.com
}

SUMMARY

\begin{abstract}
The complex anatomical structure of the ewe reproductive tract accompanied with low quality of frozen ram semen for artificial insemination, resulted in a challenge with regard to using superior genotypes for reproductive ovine performance. Hence, improved genetics in ovine management has not been efficiently and widely used especially in undeveloped countries. Therefore, intrauterine semen deposition by laparoscopic insemination should be adopted in the current sheep production systems. Thus, this study aimed to assess the pregnancy rate and lambing rate of ewe inseminated by laparoscopic insemination techniques using frozen-thawed semen. The research used imported frozen semen from two rams of the Lacaune breed. Ewes were grouped according to age in years (1,2 and 4). Before insemination, the semen was examined microscopically for its motility and viability and thereafter the laparoscopic artificial insemination technique was performed to 19 Lacaune breed ewes using frozen-thawed semen. The overall pregnancy and prolificacy rates were $31.57 \%$ and $42.10 \%$ respectively. Out of 2 ewes in the 1-year age group that were inseminated, only 1 ewe lambed representing 50\%. However, from 16 ewes inseminated of four-year age group, 5 ewes lambed representing 31.25\%. Significant difference based on age group was not evaluated due disproportionate of the data, (such that the data included 2 ewes in one-year-old age, 1 ewe in 2-year-old age and 16 ewes in 4-year-old age). Based on the ram semen, $33.33 \%$ and $30 \%$ of the inseminated ewes were pregnant from ram A and ram B semen respectively. However, in the case of prolificacy rate, $44.44 \%$ and $40 \%$ of the ewes lambed from using semen of ram $A$ and $B$, respectively. There was no significant difference $(p>0.05)$ in pregnancy and prolificacy rates based on semen from the two rams. In conclusion, in this research study, ram semen had no significant effect on pregnancy and prolificacy rates using laparoscopic AI on Lacaune sheep. This could be due to the fact that the rams had very good quality semen. Evaluation of ram semen, accompanied with appropriate ewe selection based on age and rightful deposition of semen could lead to better and more consistent results. Overall this could contribute to the successful application of laparoscopic artificial insemination in Lacaune sheep production systems for enhanced productivity.
\end{abstract}

Keywords: ewes, frozen-thawed semen, laparoscopic artificial insemination, pregnancy rate, prolificacy rate

\section{INTRODUCTION}

Artificial insemination (AI) is one of the assisted reproductive technologies (ART) used in the production of farm animal that has revolutionized to breed livestock (cattle) within the past few decades. Artificial insemination achieves a higher pregnancy rate even if using low- quality semen with improved efficiency in techniques of semen preservation and estrus synchronization, including in small ruminates (Dun et al., 1955). In sheep production, AI is one of the main ART which has contributed in a higher degree to the genetic improvement for the introduction of desirable genes that better-quality production traits and controlled disease spread, but the application of AI in sheep production is relatively still limited globally (Faigl et al., 2012), due to many factors that have affected AI success in sheep, its technique and skill as the main factors affecting fertility after AI (Anel et al., 2005).

Artificial insemination is a powerful tool in sheep breeding programs for making rapid genetic progress of the flock, however, its implementation in sheep production mainly using frozen-thawed semen the fertility rates are low, due to the highly complex anatomical structure of ewe's reproductive tract, which prevents deep insemination and decreases the efficiency of the methods (Salamon et al., 2000). Currently, laparoscopic artificial insemination (LAI) is an unconventional technique for using frozen semen (Eppleston et al., 1995).

Thus limitation mainly due to great inconsistency of its fertility and the specific complications that are existed by its application, the problem to developing sheep AI belongs to the routes of application that is limited by the anatomy of the ewe's reproductive tract (Kershaw et al., 2005). Therefore, AI in sheep breeding program by laparoscope is the most widely practiced technique, that consents deposition of semen directly into the uterine horns through surgically, to overcoming the limitations of AI in sheep such as the anatomy of the cervix, differently from other species (equine, swine, bovine), the insemination pipette does not allow the passes into the fertilization site (Kershaw et al., 2005); and low fertilizing ability of frozen-thawed semen and is damaged easily by oxidative stress due to cold shocks (Gillan et al., 1999). Furthermore, it has advantages, inseminating a dose with lower sperm concentration, the spermatozoa being deposited closer to the fertilization site. However, it is a surgical procedure requiring anesthesia, highly sophisticated instrument and trained persons. In the previous years, many researchers have been made to overcome the drawbacks of AI in the sheep industry, primarily focusing on the cervical obstacle, apart from that hormonal treatment inducing cervical relaxation (Falchi et al., 2012; Macías et al., 2017), design of catheters revised due to the twisting lumen of the cervix 
(Álvarez et al., 2012) and changes in the insemination technique (Halbert et al., 1990) have been tried in the past decades but the results are still controversial.

Laparoscopic artificial insemination has acceptable results with both frozen-thawed and fresh semen and its insemination has many advantages in sheep breeding program to get maximum production and high fertility rates the cervix of the ewes is one of a physical barrier for the passage of AI pipette (Lightfoot and Salamon, 1970). Hence, laparoscopic insemination had been used to overcome this problem. Mckelvey et al. (1985) reported that the fertilization rate from synchronized ewes was $89 \%$ by using laparoscopic and fresh semen (Evans, 1987). However, the laparoscopic AI method is preferable for frozen-thawed semen, and the conception rates are comparable to the natural service, using the fresh semen (Maxwell, 1986). Similarly, Rodriguez et al. (1990) reported that the conception rate was $71 \%$ with LAI using frozen semen. Additionally, the conception rates have been reported ranging from 50-80\% by Maxwell, 1986). Even though, laparoscopic AI with frozen-thawed semen gives commercially acceptable results, it is requiring well trend person and animal welfare problem issue, but the pregnancy rate using frozen semen deposited AI via laparoscopy has yielded a higher pregnancy rate consistently when compared to trans cervical artificial insemination (TCAI) methods (Hunton, 2007). Therefore, the aim of this study was to evaluate the application of laparoscopic AI in a conventional Lacaune sheep farm using frozen-thawed semen.

\section{MATERIALS AND METHODS}

\section{Farm and animal management}

This research was conducted in a Lacaune sheep farm in the eastern parts of Hungary in Hajdú-Bihar County from October 2019 to March 2020. The experiment was carried out during the breeding season using a total of 19 Lacaune ewes aged between 1 to 4 years old, with a body condition score of 2.5-3.0. The flock was composed of milk Lacaune breed which has in total 50 heads of animals. All animals were kept in the same management system. The main source of feed was grass hay and pasture supplemented with concentrate feeds.

\section{Selection of ewes and experiment}

Thirty-two ewes were synchronized Chrono-Gest intravaginal sponges (MSD Animal Health) for a 14 days' treatment followed by Folligon injection 500IU pregnant mare serum gonadotrophin (PMSG) at the time of sponge withdrawal was administered, ChronoGest intravaginal sponges was inserted into the vaginal, used for estrus synchronization and PMSG through injection, used to increase the ovulation rate and stimulate follicular development. Out of 32 Lacaune ewes synchronized, nineteen ewes with the signs of heat were selected for insemination. All animals were deprived of feed and water for 12 hours before insemination and experimental procedures were carried out according to European regulations on the Care and
Welfare of Animals in Research (Animal Welfare Quality, 2009 article 8 and DEFRA, United Kingdom. 2009. Animal Welfare Research).

\section{Semen evaluation}

The frozen-thawed Lacaune ram semen (which has been imported from France) was evaluated before insemination with light a microscope by using $40 \mathrm{X}$ magnification power. The semen was microscopically examined for its motility and viability. In this study, the motility of the semen was ranged between $40-60 \%$ and the volume of the semen was recorded $0.5 \mathrm{ml}$ dose per ewes. The ram semen at a time of insemination, the straws were thawed in a water bath at $37-38{ }^{\circ} \mathrm{C}$ for 30 seconds. In this study $0.5 \mathrm{ml}$ per ewes with the concentration of spermatozoa 100 million cell spermatozoa and the motility of sperm $40-60 \%$ were used.

\section{Surgical procedure}

Ten minutes before the surgery, the ewes received an anesthetize treatment using Domosedan inj. A.U.V. (Detomidine Hydrochloride $\left(\mathrm{C}_{12} \mathrm{H}_{14} \mathrm{~N}_{2} \cdot \mathrm{HCl}\right)$ ) to avoid pain during surgical procures and adjust with the appropriate insemination place (laparoscopy cradle) and to ensure every necessary materials and solution were available. The area is surgically scrubbed with $70 \%$ isopropyl alcohol. Both the left and right sides of the mammary gland were identified and prepared the abdominal region by shearing the wool and disinfect the skins before surgery. The laparoscope AI cradle was elevated up and the ewe's position was in recumbence head down (Trendelenburg position by using the cradle). The scalpel blades used to create the holes through the skin on both sides of the mammary gland.

\section{Laparoscopic artificial insemination}

Ewes were subjected to laparoscopic artificial insemination at 54-56 hours after Chrono-Gest intravaginal sponge removal and PMSG injection. Then ewes were put on the cradle (Trendelenburg position) and the ewe position in a recumbence for the head down. The scalpel blades were used to create around 0.5 -inch hole through the skin in the mammary gland on both side and the inseminating gun was introduced into the lumen of the uterus horn and $0.5 \mathrm{ml}$ per ewe of frozen-thawed semen containing 100 million sperm cell was deposited in techniques. After laparoscopic AI, all ewes had received Betamox LA A.U.V (antibiotics) and NSAIDs (non-steroid antiinflammatory drugs) to protect infection and the risk of bleeding and blood cloting, respcetively.

\section{Pregnancy and prolificacy rates}

The pregnancy test was detected by an ultrasound machine after 30 days of insemination.by using abdominal ultrasonography using a MINDRAY DP-30 (China) Lambing rate was recorded after 5 months of pregnancy during the times of lambing. 
The pregnancy and prolificacy rates per ewes were determined by using the following equation:

Pregnancy rate $(\%)=($ Number of pregnant ewes/ Number of inseminated ewes) $x 100$

Lambing rate $(\%)=$ (Number of ewes lambed/ Number of inseminated ewes) x100

Prolificacy rate $(\%)=$ (Number of lambs born/ Number of ewes lambed) x 100

\section{Data analysis}

The collected data were analyzed using SPSS version 26. The data were presented in table and graph form. The age and semen which was collected from two rams were considered to check the difference. Difference between pregnancy and prolificacy rates were considered to be significant at $\mathrm{p}<0.05$.

\section{RESULTS AND DISCUSSION}

\section{Characteristics of ewes used for insemination}

In Table 1 below, the age category, date of pregnancy tests and result, lambing date, treatment, the source of semen from two rams and date of insemination were shown. Sixteen ewes were aged 4 years old, 2 ewes were 1-year-old and only one ewe was 2 years old. Nine ewes were inseminated with semen derived from ram $\mathrm{A}$ and 10 ewes inseminated by semen taken from ram $\mathrm{B}$. The result revealed that all ewes tested positive/pregnant for pregnancy test were lambed.

Characteristics of ewes used for insemination

Table 1

Characteristics of ews used for insenination

\begin{tabular}{|c|c|c|c|c|c|}
\hline Ewe ID & Age of ewe (year) & Pregnancy test ${ }^{*}$ & Lambing date & Ram & $\begin{array}{c}\text { Treatment } \\
\end{array}$ \\
\hline 5209 & 4 & NP & - & A & Chrono-Gest intravaginal sponges \\
\hline 50049 & 4 & NP & - & & (MSD Animal Health) for a 14 days' \\
\hline 50063 & 4 & NP & - & & treatment followed by Folligon \\
\hline 50191 & 4 & NP & - & & injection 500IU pregnant mare serum \\
\hline 50201 & 4 & $\mathrm{P}$ & March 04, 2020 & & gonadotrophin (PMSG) \\
\hline 50203 & 4 & $\mathrm{P}$ & March 05, 2020 & & \\
\hline 50214 & 4 & NP & - & & \\
\hline 50225 & 4 & $\mathrm{P}$ & March 04, 2020 & & \\
\hline 50230 & 4 & NP & - & & \\
\hline 50235 & 4 & NP & - & $\mathrm{B}$ & \\
\hline 702 & 2 & NP & - & & \\
\hline 811 & 1 & NP & - & & \\
\hline 813 & 1 & $\mathrm{P}$ & March 05, 2020 & & \\
\hline 50033 & 4 & NP & - & & \\
\hline 50181 & 4 & NP & - & & \\
\hline 50184 & 4 & $\mathrm{P}$ & March 07, 2020 & & \\
\hline 50215 & 4 & $\mathrm{P}$ & March 06, 2020 & & \\
\hline 50216 & 4 & $\mathrm{NP}$ & - & & \\
\hline 50224 & 4 & $\mathrm{NP}$ & - & & \\
\hline
\end{tabular}

${ }^{*}$ All ewes were inseminated on October 10, 2019 and pregnancy test was on November 8, 2019, NP: none pregnant, P: pregnant

Pregnancy and prolificacy rates based on the age of ewes

The overall pregnancy rate was $31.57 \%(6 / 19)$ and the prolificacy rate was $42.10 \%(8 / 19)$ (Table 2). Pregnancy rate of ewes aged 4 years old was $31.25 \%$ and 1-year-old was $50 \%$ (Table 2). Prolificacy rate of aged 1-year-old was $50 \%$ and aged 4 years old was $43.75 \%$ (Table 2). Because of the disproportionate nature of data, the significant difference between age groups was not tested.

Pregnancy and prolificacy rates according to the age of ewes

\begin{tabular}{ccccccc}
\hline $\begin{array}{c}\text { Age of ewes } \\
\text { (years) }\end{array}$ & $\begin{array}{c}\text { Number of } \\
\text { inseminated ewes }\end{array}$ & $\begin{array}{c}\text { Number of } \\
\text { pregnant }\end{array}$ & $\begin{array}{c}\text { Pregnancy } \\
\text { rate (\%) }\end{array}$ & $\begin{array}{c}\text { Number of } \\
\text { lambed }\end{array}$ & $\begin{array}{c}\text { Number of } \\
\text { lambs born }\end{array}$ & $\begin{array}{c}\text { Prolificacy } \\
\text { rate (\%) }\end{array}$ \\
\hline 1 & 2 & 1 & 50 & 1 & 1 & 50 \\
2 & 1 & 0 & 0 & 0 & 0 & 0 \\
4 & 16 & 5 & 31.25 & 5 & 7 & 43.75 \\
\hline Total & 19 & 6 & 31.57 & 6 & 8 & 42.10 \\
\hline
\end{tabular}

Pregnant rate: number pregnant/ number of inseminated X100\%, Prolificacy rate: number of lambs born /number of inseminated X100\% 
Age of ewe is among several factors that affect the efficiency of LAI, specifically pregnancy and lambing rates in sheep breeding programs (Anel et al., 2005). As a result, it must be considered during application LAI in the sheep sector. Therefore, in this study the age of ewe was one of the factors taken into consideration to evaluate its effect on pregnancy and lambing rates by LAI in Lacaune breeds using frozen-thawed semen. Because of the disproportionate nature of data in the current study, the statistically significant difference between age groups for pregnancy and prolificacy rates was not evaluated. However, the result revealed that the pregnancy rate of ewes aged 4 years old was $31.25 \%$ and 1-year-old was $50 \%$. Prolificacy rate of aged 1year-old was $50 \%$ and aged 4 years old was $43.75 \%$, this result is supported by the finding of Shackell et al. (2000) who indicated that fertility of ewe decreases when the age increases that are due to the reproductive disorder may occur during the parturition.

The fertility rates of older ewes were reduced as the significance of the decrement, the oocyte qualities (Arranz et al., 2008; Fukui et al., 2010; Palacin et al., 2012). According to Esmailizadeh et al. (2009) report when the age of ewes increases from 2 to 7 years, the fertility rate of ewes declined from 29 to $5 \%$. It was similar in this study when the age of ewe increases from 1 to 4 years, the pregnancy and prolificacy rates decreased by 18.75 and $6.25 \%$, respectively. This indicates that the young ewes have relatively good fertility as compared to older ewes. Besides, a decrease in fertility rate due to increment in age might be described in the fact that older ewes have expanded risks of the reproductive issue and diminished ovulation rates contrasted with younger ewes.

The investigation from Spain on the Churra dairy type sheep breed by Anel et al. (2005) depicted that while after 1.5 years old, the prolificacy rate decreased by $1.74 \%$ every year for cervical AI. The most important result of fertility rate declined with age were described in the Lacaune breed by Colas et al. (1973), who revealed a reduced fertility of $15 \%$ per year. In this study the pregnancy and prolificacy rates decreased by $18.75 \%$ and $6.25 \%$ respectively, when the age of the ewe's increases. However, as indicated by Anel et al. (2006) younger ewes show decreased fertility because of their consideration with more seasoned ewes that normally lamb prior. Furthermore, nutritious deficiencies are regularly seen in younger ewes during the reproducing time frame because of their more necessity for development and body maintenance.

The author Alabart et al. (2002) illustrated that the most extreme fertility $(56.7 \%)$ was detected at 3 years old ewes matured from 2 to 5 years that means the fertility rate value above $50 \%$. Similarly, Colas et al. (1973) described that the fertility rate decline when ewes inseminated over 3.5 years old, and Gabiña and Folch (1987), described that the fertility of ewes strongly falls, ewes inseminated at 4 and more years' age. Fertility decreases because of the number of previous parturition (lambing). Moreover, in different investigation, the better fertility was obtained at 2 years old age with a progressive fall afterward (Fantova, et al., 1998). In the case of this study also at 2 years old ewes the fertility rate was not pregnant, due to small number of ewes inseminated, the correlation between the numbers of ewes inseminated to lambed is positive.

\section{Pregnancy and prolificacy rates based on semen from two rams}

The pregnancy and prolificacy rates of semen from ram A was $33.33 \%$ and $44.44 \%$, respectively (Table $3)$. In case of, semen from ram B, pregnancy and prolificacy rate was 30 and 40\%, respectively (Table 3). There was no significant difference $(p>0.05)$ between semen from ram $\mathrm{A}$ and ram $\mathrm{B}$.

Pregnancy and prolificacy rates based on semen from two rams

\begin{tabular}{ccccccc}
\hline Ram & $\begin{array}{c}\text { Number of } \\
\text { inseminated ewes }\end{array}$ & $\begin{array}{c}\text { Number of } \\
\text { pregnant }\end{array}$ & $\begin{array}{c}\text { Pregnancy } \\
\text { rate (\%) }\end{array}$ & $\begin{array}{c}\text { Number of } \\
\text { lambed }\end{array}$ & $\begin{array}{c}\text { Number of } \\
\text { lambs } \\
\text { born }\end{array}$ & $\begin{array}{c}\text { Prolificacy } \\
\text { rate }(\%)\end{array}$ \\
\hline A & 9 & 3 & 33.33 & 3 & 4 & 44.44 \\
B & 10 & 3 & 30 & 3 & 4 & 40 \\
\hline Total & 19 & 6 & 31.57 & 6 & 8 & 42.1 \\
\hline
\end{tabular}

Pregnant rate: number pregnant/ number of inseminated X100\%, prolificacy rate: number of lambs born /number of inseminated X100\%

Several authors described that ram has an effect on the pregnancy rate in sheep production from one to another. The same quality ram semen produced from different rams and handled under the same conditions could show significant variations in the fertility rate. Therefore, fertility variations have been described in ewes cervical inseminated with fresh semen (Paulenz et al., 2002; Anel et al., 2005) and using frozen-thawed semen (Olesen, 1993; Eppleston et al., 1995; Paulenz et al., 2007). The reasons why these variations are undefined between each ram are, some seminal parameters, such as motility and the number of spermatozoa per portion or dose (Paulenz et al., 2002). Selection or determination of exceptionally highly fertile ram may improve the results of insemination programs and accelerate the spreading of genetic improvement in breeding programs. In this study we used frozen-thawed semen from two rams of the same Lacaune breed and there was no significant difference in the pregnancy and the prolificacy rates, which means that, the pregnancy rate was $33.33 \%$ and $30 \%$ for ram $\mathrm{A}$ and $\mathrm{B}$ respectively. In the case of prolificacy rate, it 
was $44.44 \%$ and $40 \%$ for ram A and B respectively. Therefore, the significant difference between them ( $\mathrm{p}>$ 0.05). Furthermore, this result is supported by (Salamon and Maxwell, 1995) who established that ram semen fertility difference could be due to genetic of the ram. In addition to the strict selection of the ejaculates, the semen from each ram should be evaluated independently for successful LAI (Windsor., 1997; Wulster et al., 2002).

The ram semen is very sensitive to freezing and cold shock, however, insemination using frozen-thawed semen deeply laparoscopically results are favorable, even though it needs minimal surgery, cost and welltrained persons (Anel et al., 2005). The reproductive achievement of ewes after insemination can be affected by several factors, including the husbandry practice of ewes, age of ewes, season, the synchronization protocol and the technique of insemination (Anel et al., 2005, David et al., 2008, Fukui et al., 2010). The insemination technique itself, including semen quality assessment, semen preservation and determination of the optimal sperm number per insemination dose, is also important for optimum ewe's fertility (Anel et al., 2005). In this study the insemination technique was performed by highly experienced inseminator using a $0.5 \mathrm{ml}$ dose per ewe containing 100 million spermatozoa cells in both ram semen.

\section{CONCLUSIONS}

The anatomical barriers of the ewe's reproductive tract and the frozen-thawed semen of rams is limiting factors in spreading superior genetic values in the sheep production. AI technique is preferable in sheep breeding programs but still the pregnancy rate of the ewes is not achieved to $100 \%$. Even if the procedure requires surgical skill person and costly equipment, the deposition of semen at the horn of ewe's uterus, results in acceptable pregnancy and prolificacy rates as compared to other insemination methods. In order to overcome these problems, the laparoscopic AI technique is one of the recent technologies to solve the limitations of AI in sheep production with high quality ram semen's.

In conclusion, age of ewes, semen deposition site and different ram semen were the factors affecting pregnancy and prolificacy rates after LAI on Lacuane sheep. From the results above, it can be concluded that the ram semen has no effect on pregnancy and prolificacy rates. The overall pregnancy and prolificacy rates were below $50 \%$, which was unfavorable as compare to international data because the study was field trial. Therefore, based on the conclusion above, it can be recommended as hence, the research could be repeated with a higher number of ewes to give more accurate and significant results and evaluation of ram semen, appropriate selection of ewes based on age and deposition of semen, could lead to better and more constant results, contributing to the spread of LAI application in Lacaune sheep intensive flocks in larger scale production. Furthermore, laparoscopic AI will allow us to obtain protocols suitable for each factors, promoting the dissemination of superior genetic material at a reduced cost for sheep smallholders.

\section{Conflict of Interest}

The authors declare no conflict of interest. The research was conducted in the absence of any commercial or financial relationships that could be construed as a potential conflict of interest.

\section{REFERENCES}

Alabart, J.L.-Folch, J.-Ciudad, M.A.-Fantova, E.-Sevilla, E.Quintin, F.J. (2002): Efecto dela edad de la oveja rasa aragonesa sobre la fertilidad en la inseminación artificial (I.A.) dentro del esquema de mejora de la UPRA-OVIARAGÓN S.C.L, Proceedings of: XXVII Congreso de la Sociedad Española de Ovinotecnia y Caprinotecnia, Valencia (España).

Álvarez, M.-Chamorro, C.A.-Kaabi, M.-Boixo, J.C.-Anel, E.Anel, L.-de Paz, P. (2012): Design and "in vivo" evaluation of two adapted catheters for intrauterine trans cervical insemination in sheep. Anim. Reprod. Sci. 131: 153-159.

Anel, L.-Alvarez, M.-Martinez-Pastor, F.-Garcia-Macias, V.-Anel E.-de Paz, P. (2006): Improvement strategies in ovine artificial insemination. Reproduction in Domestic Animals. 41:30-42.

Anel, L.-Kaabi, M.-Abroug, B.-Alvarez, M.-Anel, E.-Boixo, J.C.De Paz, P. (2005): Factors influencing the success of vaginal and laparoscopic artificial insemination in churra ewes a field assay. Theriogenology. 63: 1235-1247.

Arranz, J.-Freret. S.-Fidelle, F.-Fatet, A. (2008): Fertility after artificial insemination in Pyrenean dairy sheep herds: individual and herd factors linked to breeding practices. Renc Rech Ruminants. 15:359-362.

Colas, G.-Thimonie, J.-Courot, M.-Ortavant, R. (1973): Fertility and reproductive efficiency during the breeding season of ewes artificially inseminated after treatment with flugestone acetate. Annales De Zootechnie. 22: 444-451.

David, I.-Robert-Granie, C.-Manfredi, E.-Lagriffoul, G.-Bodin, L. (2008): Environmental and genetic variation factors of artificial insemination success in French dairy sheep. Animal. 2: 979-986.

Dun, R. (1955): The cervix of the ewe. Its importance in artificial insemination of sheep. Journals of Vet. 31:101-312.

Eppleston, J.-Maxwell, W.M.C. (1995): Sources of variation in the reproductive performance of ewes inseminated with frozenthawed ram semen by laparoscopy. Anim Reprod. 43:777-888.

Esmailizadeh, A.K.-Dayani, O.-Mokhtari, M.S. (2009): Lambing season and fertility of fattailed ewes under an extensive production system are associated with live weight and body condition around mating. Animal Production Science. 49: 10861092.

Evans, G.-Maxwell, W.M.C. (1987): Artificial Insemination of Sheep and Goats. Butterworths, Sydney, Australia.

Faigl, V.-Vass, N.-Javor, A.-Kulcsar, M.-Solti, L. (2012): Artificial insemination of small ruminants-a review. Acta Veterinaria Hungarica. 60: 115-129.

Falchi, L.-Taema, M.-Laclanche, S.-Scaramuzzi, R.J. (2012): The pattern of cervical penetration and the effect of topical treatment with prostaglandin and/or FSH and oxytocin on the depth of 
cervical penetration in the ewe during the per ovulatory period. Theriogenology. 78:376-384.

Fantova, E.-Ciudad, M.A.-Vijil, E.-Sevilla, E.-Quintin, F.J.-Folch, J.-Sin, E.-Alabart, J.L.-Jurado, J.J. (1998): Evolution of the artificial insemination program in the genetic improvement. XXIV Jornadas Científicas de la Sociedad Española de Ovinotecnia y Caprinotecnia, Soria (España).

Folch, J.-Gabiña, D. (1987): La inseminación artificial ovina Resultados de su aplicación en un programa de selección en la raza Rasa Aragonesa, Proceedings of ITEA. Zaragoza (España).

Fukui, Y.-Kohno, H.-Okabe, K.-Katsuki, S.-Yoshizawa M. (2010) Factors affecting the fertility of ewes after intrauterine insemination with frozen thawed semen during non-breeding season. Journal of Reprod Develop. 56: 460-466.

Gillan, L.-Maxwell, W.M. (1999): The functional integrity and fate of cryopreserved ram spermatozoa in the female tract. Journal. Reprod. Fertility Suppl. 54: 271-283.

Halbert, G.W.-Dobson, H.-Walton, J.S.-Buckrell, B.C. (1990): A technique for transcervical intrauterine insemination of ewes. Theriogenology. 33: 993-1010.

Hunton, J.R. (2007): Artificial insemination and embryo transfer in sheep. Theriogenology. 629-41.

Kershaw, C.-Khalid, M.-McGowan, M. (2005): The anatomy of the sheep cervix and its influence on the transcervical passage of an inseminating pipette into the uterine lumen. Theriogenology. 64:1225-1235.

Lightfoot, R.J.-Salamon, S. (1970): Fertility of ram spermatozoa frozen by the pellet method I, transport and viability of spermatozoa within the genital tract of the ewe. Journal of Reproduction and Fertility. 22:385-398.

Macías, A.-Ferrer, L.M.-Ramos, J.-Lidón, I.-Rebollar, R.-Lacasta, D.-Tejedor, M.T. (2017): A new device for cervical insemination of sheep design and field test1. Journal of Anim. Sci. 95:5263-5269.

Maxwell, W.M.C.-Hewitt, L.J. (1986): A comparison of vaginal, cervical and intra-uterine insemination of sheep. Journal of Agric. Sci. 106: 191-193.
McKelvey, W.A.C.-Robinson, J.J.-Aitken, R. (1985): The evaluation of laparoscopic insemination technique in ewes. Theriogenology. 24:519-535.

Olesen, I. (1993): Effects of cervical insemination with frozen semen on fertility and litter size of Norwegian sheep. Livestock Prod. Sci.37: 169-184.

Palacin, I.-Yániz, J.L.-Fantova-Blasco, E.M.E.-Quintín-Casorrán, F.J.-Sevilla-Mur, E. (2012) Factors affecting fertility after cervical insemination with cooled semen in meat sheep. Anim Reprod Sci. 132: 139-144.

Paulenz, H.-Adnoy, T.-Fossen, O.H.-Soderquist, L.-Berg, K.A. (2002): Effect of deposition site and sperm number on the fertility of sheep inseminated with liquid semen. Journal of Vet. Rec. 150: 299-302.

Paulenz, T.-Adnoy, L.-Soderquist, J. (2007): Comparison of fertility results after vaginal insemination using different thawing procedures and packages for frozen ram semen. Acta Vet. Scand. Page. 49.

Rodriguez, F.-Stellflug, J.N.-Fitzgerald, J.A.-Lavoie, V.A. (1990): Invitro viability and fertilizing capacity their current and future use of sheep AI. Journal of Reproduction and Fertility. 38:1-36.

Salamon, S.-Maxwell, M.C. (2000): Storage of ram semen. Anim. Reprod. Sci. 62: 77-111.

Shackell, G.H.-Kyle, B.-Littlejohn, RP. (2000): Factors influencing the success of a large scale artificial insemination programme in sheep. Anim Prod. 50: 427-430.

Windsor, D.P. (1997): Variation between ejaculates in the fertility of frozen ram semen used for cervical insemination of Merino ewes. Animal Reprod Sci. 47: 21-29.

Wulster-Radcliffe, M.C.-Lewis, G.S. (2002): Development of a new transcervical artificial insemination method for sheep. Theriogenology. 58:1361-1371. 